\title{
Emotions in the Early Common Law (c. 1166-1215)
}

\author{
JOHN HUDSON
}

\begin{abstract}
Beyond dealing with wrongdoing and litigation, law has many other functions. It can be designed to make life more predictable, it can facilitate and promote certain actions, it can seek to prevent disputes by laying down rules, and provide routes to solutions other than litigation should disputes arise. All of these can have connections to matters of emotion. Using both lawbooks and records of cases from the Angevin period, the present article begins by looking at issues of land law rather than crime, and at law outside rather than inside court. It then returns to crime and litigation before exploring the significance of the nature of legal records for the relationship between emotion and law. In doing so, it pays attention to emotion in action, to uses of emotionally-charged language, to appearances of the vocabulary of emotions, and to the routinized use of words that might at other times or in other contexts have an emotional element. Underlying the analysis is an exploration of the ways in which some aspects of law became more discrete from ordinary social practice and discourse, in this instance through elements of distancing from emotion.
\end{abstract}

Keywords: Law, Legal History, Medieval, England, Glanvill, Alienability, Plea rolls. 


\section{INTRODUCTION}

The majority of work on the history of emotions and law has focused on wrongdoing and on activity in courtrooms. This is true for the medieval period as for others. Particularly significant have been studies such as Paul R. Hyams' Rancor and Reconciliation, with its focus on wrongdoing and the conduct of disputes, outside and inside court, and the essays of Stephen D. White, on trials in literary texts. ${ }^{1}$ And

${ }^{1}$ Paul R. Hyams, Rancor and Reconciliation in Medieval England, Ithaca, 2003; e.g. Stephen D. White, 'The Evils of the Court: Judicial Melodramas in Medieval French Literature', in John Hudson and Sally Crumplin, eds., “The Making of Europe”: Essays in Honour of Robert Bartlett, Leiden, 2016, 184-204, and more generally 'The Politics of Anger', in Barbara H. Rosenwein, ed., Anger's Past, Ithaca, 1998, 127152, and 'The Feelings in the Feud: The Emotional Turn in the Study of Medieval Vengeance', in Kim Esmark, Lars Hermanson, Hans Jacob Orning and Helle Vogt, eds., Disputing Strategies in Medieval Scandinavia, Leiden, 2013, 281-311. Highly influential has been the work of William Ian Miller, from the consideration of vengeance in Bloodtaking and Peacemaking: Feud, Law, and Society in Saga Iceland, Chicago, 1990, to the wide-ranging explorations of emotions in "Why is Your Axe Bloody?”: A Reading of Njáls Saga, Oxford, 2014, and Hrafnkel or the Ambiguities, Oxford, 2017. For an important later medieval study, see Daniel Lord Smail, The Consumption of Justice: Emotions, Publicity, and Legal Culture in Marseille, 12641423, Ithaca, 2003. From still later periods, see e.g. the excellent analyses in Susanne Pohl-Zucker, Making Manslaughter, Leiden, 2017, and Mark Seymour, 'Emotional Arenas: from Provincial Circus to National Courtroom in Late Nineteenth-Century Italy', 16 Rethinking History (2012), 177-197. A version of this paper was delivered as the first lecture in the Harvard Law School European Legal History Series in April 2017, and I would like to thank members of the audience for their stimulating questions. I would also like to thank Professor Paul Brand, Merridee Bailey, and Kimberley-Joy Knight for their very helpful comments on earlier drafts of the article. Conversations with Dr Knight provided the inspiration for writing the paper and for many of its ideas, and whatever is good in it also owes much to the long-standing influences of Paul Hyams, Bill Miller, and Steve White. 
whilst writings on contemporary law and emotions point out that the field is wider than crime and litigation, those topics remain a primary focus. ${ }^{2}$

Yet beyond dealing with wrongdoing and litigation, law has many other functions. It can be designed to make life more predictable, it can facilitate and promote certain actions, it can seek to prevent disputes by laying down rules, and provide routes to solutions other than litigation should disputes arise. All of these can have connections to matters of emotion. Using both lawbooks and records of cases from the Angevin period, the present article begins by looking at issues of land law rather than crime, and at law outside rather than inside court. It then returns to crime and litigation before exploring the significance of the nature of legal records for the relationship between emotion and law. In doing so, it pays attention to emotion in action, to uses of emotionally-charged language, to appearances of the vocabulary of emotions, and to the routinized use of words that might at other times or in other contexts have an emotional element. Underlying the analysis is an exploration of the ways in which some aspects of law became more discrete from ordinary social practice and discourse, in this instance through elements of distancing from emotion.

\section{CONTROL OF ALIENATION OF LAND}

Land was the crucial resource of the powerful, and indeed the less powerful, in the medieval period. Control of land and access to it, its passing between generations, and its grant to others, were essential to the maintenance and extension of power. Landholding could be closely connected to personal relationships involving elements of emotion, formalized or less formalized, notably in our period with the conjuncture of the tenurial and the homage bonds. ${ }^{3}$ In the distribution of land, be it within the

\footnotetext{
${ }^{2}$ Excellent starting points are Susan A. Bandes, ed., The Passions of Law, New York, 1999; Kathryn Abrams and Hila Keren, ‘Who’s Afraid of Law and the Emotions?', 94 Minnesota Law Review (2010), 1997-2074.

${ }^{3}$ See esp. Stroud F. C. Milsom, The Legal Framework of English Feudalism, Cambridge, 1976; John Hudson, Land, Law, and Lordship in Anglo-Norman England, Oxford, 1994.
} 
family or without, issues of emotion were likely to meet with issues of law. ${ }^{4}$ Affection could be an appropriate motive for a grant, and emotion could also enter into grants in a variety of other ways. ${ }^{5} \mathrm{~A}$ famous charter from mid-twelfth-century England presents the son's obligation to maintain his father's gift to a church in emotive terms, even if without specific emotion words - indeed emotional force is conveyed through legal imagery:

if this man's heir should try to take away the alms which is interposed as a bridge between his father and Paradise, by which his father may be able to pass over, the heir, so far as he may, is disinheriting his father from the kingdom of heaven, and therefore by right shall not obtain the remaining inheritance, since he who has killed his father has proved himself no son. ${ }^{6}$

Furthermore, certainly at the time of this charter, crucial aspects of the alienability of land were not a matter of fixed, hard rules. Rather there was room for negotiation, and also for problems to arise, notably through conflicting views of reasonable practice. In the same charter, the donor is made to say:

I have done this by the advice and with the approval of many wise men, moved especially by the exhortation, requests and counsel of the lord Theobald, archbishop of Canterbury and primate of all England, who showed me by the most reasonable and unanswerable arguments (racionabilibus et uerissimis assercionarum) that it is most just that a noble and generous man who has a fief of six knights should bestow not only the third part of a knight's land on God and the holy church for the health of his own soul and his kin's, but the whole of a knight's land or more than that.

\footnotetext{
${ }^{4}$ Note esp. Stephen D. White, 'The Discourse of Inheritance in Twelfth-Century France: Alternative Models of the Fief in "Raoul de Cambrai”', in George Garnett and John Hudson, eds., Law and Government in Medieval England and Normandy: Essays in Honour of Sir James Holt, Cambridge, 1994, 173-197.

${ }^{5}$ See Curia Regis Rolls, London, 1922-present, vol.1, 389, for a woman in a 1201 case saying that she had been persuaded into a grant by a mixture of threats, tricks, and sweet-talking, such that she was persuaded that she loved the grantee, and he loved her.

${ }^{6}$ Sir Frank Stenton, The First Century of English Feudalism, 2nd ed., Oxford, 1961, 38-40, 260-261.
} 
Clearly in this case there was no simple formula for how much might be given to the church. It was a matter for persuasion by the greatest prelate in the land, suggesting that either donor, or other parties, or both, may have had potentially conflicting interests in, and attachments to, the land. Use of the adjective 'reasonable [racionabilis]' could indicate that one method of persuasion that the archbishop used was to differentiate in carefully logical fashion what was proper from what was emotionally desired by the parties who needed persuading; at the same time, the archbishop was selling his ideas in an emotional fashion, in his appeal to close family bonds.

The discussion of alienation in Book VII of the lawbook known as Glanvill (c. 1188) contains much that sounds purely technical law but emotion too is mentioned. ${ }^{7}$ The anonymous author operates within a framework of reasonableness as to the amount that is alienable. He is particularly concerned with situations where disputes might arise, where there might be a perception of unreasonableness. In such circumstances emotional expectation and legal norm might come into conflict.

Glanvill distinguishes between the man who has only land that he has inherited, the man who has only land that he has acquired, and the man who has both. In the case of the man who has only inherited land, the author confronts an apparent anomaly, where law and expected emotion conflict. The landholder

can, as has been said, give a certain part of that inheritance to any stranger he wishes. However, if he has several legitimate sons, he can hardly give any part of the inheritance to a younger son without the heir's consent; for if this were allowed, the disinheritance of eldest sons would often occur, because of the greater affection [maiorem ... affectionem] that fathers tend to have for younger sons. ${ }^{8}$

\footnotetext{
${ }^{7}$ Tractatus de Legibus et Consuetudinibus Regni Anglie qui Glanvilla Vocatur, ed. and trans. G. Derek G. Hall, Edinburgh, 1965. For a brief summary of views on authorship, see John Hudson, The Oxford History of the Laws of England: Volume II 871-1216, Oxford, 2012, 872-873.

${ }^{8}$ Glanvill, Bk vii ch. 1, ed. Hall, 70. For important comments on ideas of affectio in the learned rhetorical tradition, ideas that possibly illuminate Glanvill's use of the word, see Rita Copeland, 'Affectio in the Tradition of the De Inventione: Philosophy
} 
Here we have law recognizing and working to prevent what is presented as the unfair effect of emotion upon behaviour. However, the author displays an awareness of the incongruity of the situation. He here mentions the fact that a grant to a stranger required no consent. He goes on to mention a still more striking contrast to the situation with a younger son: 'Can a man who has a son and heir give from his inheritance to his bastard son? If he can, then the bastard son will be better off in this matter than the legitimate son; notwithstanding this, he can do so'. ${ }^{9}$ Here a rule of law is having an effect that is unexpected, both socially and emotionally. One sees a classic instance of legal development: law solves a problem, that of potential excessive generosity to younger sons, yet in this instance the solution creates an anomaly.

It could be that the mention of fathers' favour for younger sons is in some way related to Henry II's favour for his youngest son, the future King John. This relationship is relevant for a discussion slightly later in Book VII, of the so-called casus regis, 'the king's case': 'when anyone dies leaving a younger son, and a grandson born of the eldest son already dead, a great legal problem arises as to which of them is to be preferred in that succession, namely, whether the son or the grandson' ${ }^{10}$ This would be the situation facing the royal house in 1199, and which may have been under consideration at the time Glanvill was writing in the late 1180s. However, this time Glanvill's discussion does not mention issues of emotion. It could

and Pragmatism', in Georgiana Donavin and Denise Stodola, eds., Public Declamations: Essays on Medieval Rhetoric, Education, and Letters in Honour of Martin Camargo, Turnhout, 2015, 3-20, esp. 4-11.

${ }^{9}$ Glanvill, Bk vii ch. 1, ed. Hall, 70-71. If one reads Book VII as being influenced by the internal politics of the royal family, the grant of Appleby in Lincolnshire to Henry II's illegitimate son William Longéspee in 1188 may be of relevance here;

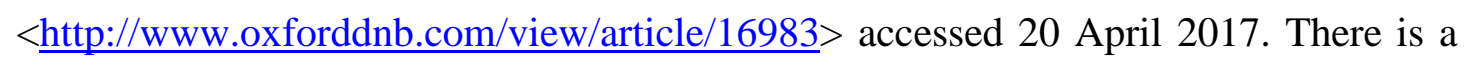
possibility that Book VII in the form we have it was not entirely produced before 1189. If the work comes from the circle of Ranulf de Glanville, his close connection to the future King John may be of importance; note <http://www.oxforddnb.com/view/article/10795> accessed 1 Feb. 2017.

${ }^{10}$ Glanvill, Bk vii ch. 3, ed. Hall, 77. 
be that this silence was because the problem was a specifically legal one, and the author did not feel obliged to raise issues of affectio. Or it could be that he chose to remain silent despite - or perhaps because of - Henry's known favour for John, instead either avoiding controversy or making a coded contribution to debate on the subject.

A further associated topic that Glanvill analyses is the norm that 'according to the law of the realm no one can be at the same time heir and lord of the same tenement'. ${ }^{11}$ Such is a clear statement of a legal norm. It appears in a discussion of gifts within the family, a discussion that begins 'because of the generosity that fathers are accustomed to display to their sons or to others in making gifts of this kind [i.e. of inherited land], certain legal problems frequently arise'. Gift-giving, and its possible legal consequences, are thus again seen as arising from an impulse that could at least in part be emotional, generosity [liberalitas]. Here problems are foreseen, for example with a gift made to a second son, who predeceases his father. Who should succeed? Glanvill's discussion proceeds according to the logic of rules of law, allowing no room for emotion or indeed for what might be the legally-uninformed social expectation. ${ }^{12}$ Only with seeming reluctance does he allow that the king's court might in particular circumstances reach a decision contrary to the logic of the rules, 'out of equity', thereby allowing greater room for an outcome that was acceptable in terms of social and emotional expectation. ${ }^{13}$

Another instance where emotion might enter into giving in ways that could lead to dispute was the deathbed gift, where loss of reason might lead to bad decisionmaking, at least in the eyes of those who lost out: ${ }^{14}$

${ }^{11}$ Glanvill, Bk vii ch. 1, ed. Hall, 72; note the repeated use of the word 'ratione'.

${ }^{12}$ See further John Hudson, 'From the Leges to Glanvill: Legal Expertise and Legal Reasoning in Twelfth-Century England', in Stefan Jurasinski, Lisi Oliver, and Andrew Rabin, eds., English Law before Magna Carta: Felix Liebermann and Die Gesetze der Angelsachsen, Leiden, 2010, 221-249.

${ }^{13}$ Glanvill, Bk vii ch. 1, ed. Hall, 74.

${ }^{14}$ Note e.g. Curia Regis Rolls, vol.1, 352-353, where a man is said to have made a charter on his deathbed, 'which he ought not and could not according to the custom of the realm'. See also e.g. ibid., vol.1, 257, for a gift being challenged on the grounds 
although the general rule is that any person is allowed to give freely in his lifetime a reasonable part of his land to whom he wishes, this has not hitherto been permitted for those about to die, because there might be an extravagant distribution of the inheritance if it were permitted to one who loses both memory and reason in the turmoil of his present suffering [feruore passionis instantis et memoriam amittit et rationem], a common enough happening. ${ }^{15}$

Reason would have ensured a proper distribution of the inheritance, the donor remembering all those who should receive grants; excessive emotion conflicted with reasonableness, and law was to be on the side of reason. A particular fear, although one not specified by Glanvill, was pressure from ecclesiastics seeking that a dying person give to the church in the hope of improving chances of salvation. According to an early thirteenth-century chronicle, in the 1190 s some men claimed that, by a recent law,

no one, however great, who had taken to his bed because of illness, is to be permitted in his final will to bequeath to anyone anything from his lands or tenements that he had possessed up until then, nor even be able to confer them on monks, who are beloved beyond others [pre aliis dilectis]. ${ }^{16}$

Although there is no further precise evidence about this claimed law, this passage remains significant: as in Glanvill, so also elsewhere, law could be deliberately presented as a means of restricting or preventing any unreasonable effect threatened by what might be classified as improper emotion.

There are further instances where Glanvill explains law in terms of preventing disputes linked to emotion. ${ }^{17}$ One is the need for seignorial consent when a man

that it was made on the donor's deathbed. In both these cases the beneficiaries of the grants were churches. Note further, e.g., ibid., vol.1, 386-387, vol.6, 351-352.

${ }^{15}$ Glanvill, Bk vii ch. 1, ed. Hall, 70.

${ }^{16}$ The Book of the Foundation of Walden Monastery, Bk iv ch. 18, ed. and trans. Diana Greenway and Leslie Watkiss, Oxford, 1999, 144. For pressure from clerics, note also Hudson, Land, Law, and Lordship, 195 n.97, Hudson, Oxford History, 362 n.167.

${ }^{17}$ Note also Glanvill, Bk vii ch. 12, ed. Hall, 86, on incontinence of an heiress or widow. 
without sons wished to marry off a daughter, in such circumstances an heir. In this case the issue is explained in terms of enmity:

the reason for this is that, since the husband of the heiress is bound to do homage to the lord for that tenement, the agreement and consent of that lord is necessary for doing it, lest he be forced to receive homage concerning his fee from his enemy or some other unsuitable person. ${ }^{18}$

Elsewhere Glanvill discusses further situations in which emotional conflict was likely to cause, and be intertwined with, legal conflict. ${ }^{19}$ In such instances we may see law as being intended to prevent future arguments at likely emotional flashpoints. One such issue is a woman's dower claims on lands that her husband had acquired after their marriage. Again Glanvill presents his material and his opinions as simple matters of law, without the language of emotions that appear occasionally in his discussion of alienability: 'for it is a general rule that, however much dower and of whatever kind is assigned to a woman, if she consents to this assignment of dower at the church door she cannot in future lawfully claim [petere] any more as dower' ${ }^{20}$ At the same time, his text can be read as revealing something of the emotions that might be involved in husband-wife property arrangements:

Any married man may give or sell or alienate in whatever way he pleases his wife's dower during his life, and his wife is bound to consent to him in this as in all other matters that do not offend against God. Indeed, to such an extent is a woman bound to obey her husband that if he wishes to sell her dower and she opposes him, and afterwards the dower is in fact sold and purchased, she cannot, when her husband is dead, claim [petere] the dower from the

${ }^{18}$ Glanvill, Bk vii ch. 12, ed. Hall, 85.

${ }^{19}$ See e.g. Glanvill, Bk vii ch. 5, ed. Hall, 79, on heirs observing testaments; note also Bk x ch. 14, ed. Hall, 129-130, on the law of sale.

${ }^{20}$ Glanvill, Bk vi ch. 2, ed. Hall, 59-60. Glanvill's line here seems to be exceptional or misleading; on practice, see Hudson, Oxford History, 795-796; Janet S. Loengard, “"Of the Gift of her Husband”: English Dower and its Consequences in the Year 1200', in Julius Kirshner and Suzanne F. Wemple, eds., Women in the Medieval World: Essays in Honor of John H. Mundy, Oxford, 1985, 215-255; Joseph Biancalana, 'Widows at Common Law: the Development of Common Law Dower', New Series 23 Irish Jurist (1988), 255-329. 
purchaser if she confesses in court, or it is proved against her, that it was sold by her husband against her will. ${ }^{21}$

In laying down this rule, Glanvill thus admits the possibility of a wife opposing her husband, a possibility rich in space for marital emotion. Furthermore, studies of practice indicate that Glanvill underplayed the wife's position, adding a further level of complexity to the inter-relationship of law, marital emotion, and alienability of dower. $^{22}$

Law, therefore, could facilitate and render secure actions inspired by emotion, including grants of land; for example, the favoured bastard son in receipt of a land grant was the beneficiary of both law and emotion. Law could also seek to prohibit, or render reversible by legal action, conveyances of land inspired by what at least some saw as excessive, unreasonable, or transient emotions. These efforts to counter improper emotions could, in addition, encourage a further development, thereby being of significant indirect influence; particularly when dealing with such matters, the author of Glanvill sometimes contrasted reason and emotion, presenting reason as characteristic of law. Thus in certain aspects and certain situations those most influential on legal development could see law not just as a corrective for excessive emotion but more generally as properly discrete from emotion.

\section{CRIME}

Whereas little attention has been paid to the significance of emotions in the context of land law, the field of wrongdoing - what might loosely be called crime - has been much more studied. Here emotions are obviously relevant in many aspects, for example in motivation, an issue particularly illuminated by Hyams' study Rancor and Reconciliation. ${ }^{23}$ Such studies also raise issues in turn for the wider history of

${ }^{21}$ Glanvill, Bk vi ch. 3, ed. Hall, 60. Cf. Glanvill, Bk vi ch. 13, ed. Hall, 65.

${ }^{22}$ Hudson, Oxford History, 796-798.

${ }^{23}$ For the period discussed in the present paper, see esp. Hyams, Rancor, ch. 6. See further Elizabeth Papp Kamali, ‘Felonia Felonice Facta: Felony and Intentionality in Medieval England', 9 Criminal Law and Philosophy (2015), 397-421, and 'The Devil's Daughter of Hell Fire: Anger's Role in Medieval English Felony Cases', 35 Law and History Review (2017), 155-200. Emotions of course could affect land 
emotions, for example in deciding what should be classified as an emotion: can greed or covetousness be fitted within the classificatory scheme used by historians of emotion? A primary concern of the present paper is again the limitation or removal of emotion from legal matters, in the present section from litigation. Various issues could be examined. For example, there is the absence in England, as opposed to some other areas, of mortal enmity as a justification of homicide. ${ }^{24}$ There is the exclusion of anger from being 'recognized officially as a legitimate partial excuse in felony cases'. ${ }^{25}$ And there is the requirement of royal pardon for homicide in self-defence. ${ }^{26}$ Self-defence should be justified in terms of emotion, of fear for one's life; ${ }^{27}$ there should be no pre-meditation, pre-meditation here perhaps being treated as the

disputes; see e.g. Rotuli Curice Regis, ed. Sir Francis Palgrave, 2 vols, London, 1835, vol.2, 87, for disseisin 'on account of the lawsuit and hatred' between the parties. Furthermore, land disputes and crime might be inter-related; see below, 000.

${ }^{24}$ See esp. Robert Bartlett, “"Mortal Enmities”: the Legal Aspect of Hostility in the Middle Ages', in Belle S. Tuten and Tracey L. Billado, eds., Feud, Violence and Practice: Essays in Medieval Studies in Honor of Stephen D. White, Farnham, 2010, 197-212; also Hyams, Rancor, 57-58. There is a largely unnoticed reference to the king of Scots as the 'mortal enemy' of the king of England in a case recorded in Rotuli Curice Regis, vol.2, 30-31, for some of the background to which see Hugh F. Doherty, 'King Henry II's Charter for Adam, Nepos of the Sheriff of Carlisle', in Keith J. Stringer, ed., North-West England from the Romans to the Tudors: Essays in Memory of John MacNair Todd (Cumberland and Westmorland Antiquarian and Archaeological Society Extra Series 41), 2014, 87-122, esp. 112-113; note also Jordan Fantosme's Chronicle, ed. and trans. Ronald C. Johnston, Oxford, 1981, lines 432, 1175, 1584.

${ }^{25}$ Kamali, ‘The Devil’s Daughter', 199.

${ }^{26}$ See esp. Naomi D. Hurnard, The King's Pardon for Homicide before A.D. 1307, Oxford, 1969. Once juries were giving verdicts on homicide cases it was possible for them to transform self-defence cases into ones of accidental killing, allowing acquittal in court; Thomas A. Green, Verdict According to Conscience, Chicago, 1985, 89-90.

${ }^{27}$ Note e.g. Hurnard, Pardon, 84-85, 92. 
opposite of emotion. ${ }^{28}$ Killing with an implement used as an ad hoc weapon, as opposed to a knife or sword, might be taken to indicate the emotional spontaneity of killing in self-defence. ${ }^{29}$

Particularly significant are procedures de odio et atia, 'concerning hatred and spite', aimed at preventing malicious accusation. ${ }^{30}$ Procedure on this matter could take two forms. ${ }^{31}$ First there is the writ de odio et atia, which the thirteenth-century law-book known as Bracton states was intended to stop the iniquity of long imprisonment of the innocent accused of homicide, as they awaited the arrival of the eyre, the king's itinerant justices, who would try their case. ${ }^{32}$ The accusation could have been by appeal (i.e. by an individual) or by indictment (i.e. by a local jury). ${ }^{33}$ The writ ordered the sheriff to gather a jury to decide whether the person had been accused 'by hatred and spite or because he is guilty, and if by hatred and spite by what hatred and spite'. ${ }^{34}$ If the accusation had been brought through hatred and spite, it did not necessarily indicate that the accused was innocent; instead, he was to be released on bail until the arrival of the eyre. The jury were therefore delving into the

${ }^{28}$ Note also ibid., 71, on the canonist Raymond of Peñafort stating that killing in selfdefence had to be immediate if it was not to be reprehensible; delay rendered it vengeance. Pohl-Zucker, Making Manslaughter, has a very valuable analysis of premeditation and other relevant issues. The relationship of emotion and pre-meditation, and its treatment in law, is of course complex; see e.g. Dan M. Kahan and Martha C. Nussbaum, 'Two Conceptions of Emotion in Criminal Law', 96 Columbia Law Review (1996), 269-374.

${ }^{29}$ See e.g. Hurnard, Pardon, 74-75, 93.

${ }^{30}$ See ibid., 339-374; Susanne Jenks, 'The Writ and Exception de odio et atia', 23 Journal of Legal History (2002), 1-22; Hyams, Rancor, 175-183.

31 The distinction is emphasized by Jenks, 'Writ and Exception'.

32 'Henry de Bracton', De Legibus et Consuetudinibus Regni Anglie, ed. George E. Woodbine, rev. and trans. Samuel E. Thorne, 4 vols, Cambridge MA, 1968-77, vol.2, 346.

33 Jenks, 'Writ and Exception', 2.

${ }^{34}$ See Bracton, ed. Thorne, vol.2, 346-347; Early Registers of Writs, ed. and trans. Elsa de Haas and G. Derek G. Hall, 87 Selden Society (1970), CC. 109, and note also CC. 110. The writ does not appear in the earlier Registers in the volume. 
field of emotions, or of inter-personal relations formulated in terms of emotion. ${ }^{35}$ They had to examine not just whether the man was guilty or not, but whether a malicious accusation had been brought purely out of hatred and spite - many a truthful accusation may have had at least an element of hatred to it - and then further into aspects of that hatred and spite.

The second form of procedure was the exception de odio et atia. ${ }^{36}$ This was only used with respect to appeals, not presentments, but could be used regarding other felony accusations as well as those of homicide. The appellor brought his accusation; the defendant responded that the accusation was brought 'out of hatred and spite'. This issue was then put to a jury; interestingly, even though felony cases brought by appeal should in the end be decided by trial by battle, people did not simply rely on God's omniscience to produce the correct judgment. In cases at a central court, there would be need of a specially set up enquiry. ${ }^{37}$ If the case was being held at the eyre, the presentment jury might act, although, as we shall see shortly, a special enquiry might be obtained from the king by payment. The jurors were asked whether it was a 'true appeal' - i.e. one brought in good faith - or was brought through hatred and spite. If the former, the case proceeded to the normal proof. If the latter, the appeal was reported either in terms of 'hatred and spite' or in terms of injustice without mentioning hatred and spite. Such amounted to a 'not guilty' verdict, an acquittal, and on some occasions the accused was specifically said to be 'quit'. As with the writ, then, the jury was not being asked about the emotions involved in a proper appeal, but was identifying purely malicious appeals using the terminology of emotions.

Case records show how such accusations and exceptions could be tied up with underlying disputes:

\footnotetext{
${ }^{35}$ Note e.g. the works of Bartlett and Smail cited in fnn. 000, 000. The publishers' copyeditor may insist on short titles here, but we'll wait and see.

36 An 'exception' was a plea by the defendant that his opponent's accusation, complaint, or claim was inapplicable to the case, for reasons of fact or law; the defendant should not, therefore, be required to make a formal defence to the accusation, complaint, or claim.

${ }^{37}$ See e.g. Pleas before the King or his Justices, 1198-1212, ed. and trans. Doris M. Stenton, 4 vols, 67, 68, 83, 84 Selden Society (1952-67), vol.4, no.4200.
} 
John son of Thorold of Edlington appeals Andrew of Edlington that he came to the house of his father, with his force of men, and ejected those who were of his father's party and his father, and treated him in such a way that thereafter he was as a result continuously ill to the day he died; and [Andrew] there took in robbery four swords and four hatchets and two bows and fifteen arrows and two sheets and five ells of linen cloth, and his father's charters concerning his inheritance. This happened in such a way that the knights of the neighbourhood came there and found Andrew with his force of men in that house.

Andrew came and denied robbery and felony and besieging of the house and ejection of the father and his men, but acknowledged that Thorold was his uncle, the son of a priest, in such a way that the land concerned should descend to him after Thorold's death, and that when he was approaching death, Andrew kept himself in that house without any force, as in the house that ought to descend to him from his uncle, and he kept himself in that house.

[Postscript] Andrew gives ten marks to the lord king to have his judgment swiftly and to have an enquiry whether this appeal was made through just cause or through hate and spite, and to have licence to make agreement concerning another appeal, that is with Hugh his brother. Both place themselves in mercy for licence [to settle]. ${ }^{38}$

The exception de odio et atia was used quite frequently; the plea rolls of the central courts from the Michaelmas term 1203 to the Michaelmas term 1204 contain more

${ }^{38}$ The Earliest Lincolnshire Assize Rolls, A.D. 1202-1209, ed. Doris M. Stenton, 22 Lincolnshire Record Society (1926), no.594. Andrew’s underlying claim presumably was that John was illegitimate because his father was a priest; therefore Andrew was Thorold's closest heir. In relation to the other appeal, against Hugh, note no.593. See also e.g. Curia Regis Rolls, vol.6, 152-153. Note also e.g. ibid., vol.1, 230-231, where the exception persuades the appellors to withdraw; vol.1, 469-470; vol.2, 50, which is tied up with a land case, and again the exception persuades the appellor to withdraw; vol.2, 180; Earliest Lincolnshire Assize Rolls, no. 607, no.841 (where the jurors say that 'per attiam facit hoc appellum et non iusta de causa'); Pleas before the King or his Justices, vol.3, no.740, vol.4, no.3428, no.3458. 
than half a dozen entries mentioning the issue of spite being raised. ${ }^{39}$ Does this mean that it was being instrumentalized, as a means of getting trial by jury instead of trial by battle, the normal form of proof arising from accusation by appeal ${ }^{40}$ Certainly matters with an emotional element could become routinized, leaving a trace, for example, through use of emotion vocabulary. ${ }^{41}$ In this instance, however, it seems that the procedure retained its original purpose, at least in the period covered by this paper. It could be quite costly, as in the ten marks that Andrew of Edlington had to pay the king (a mark was two-thirds of a pound). And it was used not just against male but also against female appellors, whose appeals did not result in trial by battle. The exception, therefore, had not been transformed simply into a method of escaping a duel, but rather retained its purpose of countering appeals brought maliciously out of 'hatred and spite'.

\section{OFFICIAL RECORDS FROM ROYAL AND ECCLESIASTICAL COURTS}

It is notable that even in accounts of proceedings de odio et atia the plea rolls of the king's courts actually mention little about emotions displayed in the courtroom or more generally once a case had been brought; rather they describe the events behind the appeal. In practice, those making the enquiries must have looked into matters of emotion, and made decisions arising therefrom. Yet the plea rolls are characterized in these matters as elsewhere by a significant degree of impersonality. ${ }^{42}$ Only very occasionally do mentions, for example, of long-standing enmities appear. ${ }^{43}$ This

${ }^{39}$ Curia Regis Rolls, vol.3, 14, 37, 63, 94 110, 163, 202. It is not always clear in these cases exactly how or at what point the issue of spite was raised.

${ }^{40}$ Roger D. Groot, 'The Jury in Private Criminal Prosecutions before 1215’, 27 American Journal of Legal History (1983), 113-141 at 113.

${ }^{41}$ See below, 000-000.

42 A similar point is made by Hyams, Rancor, e.g. 162, 173, 190-191, 242-244. Note also e.g. Smail, Consumption, 92.

${ }^{43}$ Note Hyams, Rancor, 193-194; on plea roll entries occasionally ranging more broadly, see more generally Cyril T. Flower, Introduction to the Curia Regis Rolls, 62 Selden Society (1944), 2-5. For reference to an offence being linked to 'longstanding hatred [antiquam odium]' underlying a crime, see Rotuli Curice Regis, vol.2, 278; the 
characteristic exists from the earliest surviving plea rolls in the mid-1190s. It is easy simply to assume that plea rolls must have taken the form, included the type of matter included, that they do. Yet at some point or points decisions must have been taken as to form and content, and as to what to exclude. Could the impersonality have, for example, a link to development from records that initially were primarily financial ${ }^{44}$ Such would be a worthy subject for a separate study, albeit a necessarily speculative one.

Instead, here let us look at two cases, one criminal, the other concerning land, for which accounts survive both inside and outside plea rolls. Our first case is that of Thomas of Elderfield, which Paul Hyams has made well known. ${ }^{45}$ We have both a monastic narrative account, from a Worcester collection of the miracles of St Wulfstan, and an official legal record, from the rolls of the itinerant justices visiting Gloucestershire in $1221 .{ }^{46}$ The miracle is the restoration of the convicted man's testicles and eyes, which he had lost in the punishment of mutilation; not surprisingly, the account of the man after his punishment and of the miraculous restoration is infused with emotion, but this takes us away from the field of law. The miracle story also provides an extensive account of events that led to litigation, a tale filled with love and hate. Thomas had risen in the world, and had an affair with his lord's wife who 'kept him for about two years netted in the snares of Venus'. ${ }^{47}$ Thomas eventually repented, and the spurned woman, now widowed, eventually married a

accused claimed that the appeal was brought 'through spite'. For a 1262 plea roll entry mentioning the sighs and tears of a litigant, see Paul A. Brand, 'The Origins of the English Legal Profession', in his The Making of the Common Law, London, 1992, $1-20$ at 9 .

${ }^{44}$ Note Paul Brand, “"Multis Vigiliis Excogitatam et Inventam”: Henry II and the Creation of the English Common Law', in his Making of the Common Law, 77-102 at 95.

${ }^{45}$ Paul R. Hyams, 'The Strange Case of Thomas of Elderfield', 36 History Today (1986), 9-15.

${ }^{46}$ Pleas of the Crown for the County of Gloucester, ed. Frederic William Maitland, London, 1884, no.87; The Vita Wulfstani of William of Malmesbury, ed. Reginald R. Darlington, New Series 40 Camden Society (1928), 168-175.

${ }^{47}$ Ibid., 169. 
man named George. When George found that his wife had had an affair with Thomas during her first marriage, 'he was tortured by suspicion and, fired by marital zeal, pursued the said Thomas with inexorable hatred'. ${ }^{48}$ After a drinking session the two came to blows, and Thomas, in self-defence according to the story, raised his axe to strike George. Accidentally he scratched George's arm with the point at the back of the axe, just enough to draw blood. The account then shows George taking the correct legal steps. He complained to all whom he met that his blood had been drawn, and named who had done it. He said - untruthfully according to the account - that he had been wounded when innocent, and that Thomas was a violator of the king's peace. He returned home, and then raised the hue and cry with a horn blast, claiming that Thomas had violently invaded his house without respect for the king's peace, and wickedly [nequiter] carried off his goods like a robber [predonem], whilst George had received a mortal wound in defending his house. Those roused by the horn blast included Thomas's father, who was arrested, taken to the sheriff, and imprisoned, but then released when bailed. Thomas too was arrested and released on several occasions, presumably on bail. These events apparently took place under King John, who died in 1216. It was only under John's son Henry III that George proceeded with his appeal of wounding, and the case came before the itinerant justices in 1221. George was confident, Thomas put his trust in Christ, the Virgin Mary, and St Wulfstan, whilst weeping 'copious tears [lacrimasque ... copiosius infundens]'. ${ }^{49}$ George triumphed in the trial by battle. Although by the custom of the realm Thomas deserved hanging, the miracle account tells us that the justices mixed mercy in their judgment, and sentenced him only to castration and blinding, to be carried out by George's neighbours and relatives. They duly did so, with relish, leaving Thomas in need of his miraculous restoration.

Here, then, we have a story full of emotions, but also one that is legally informed, notably about the content of George's initial accusations and the way in which he established his case. The plea roll gives nothing of the background, be it the tale of adultery or the initial legal steps of establishing accusation and raising hue and cry. ${ }^{50}$ Time is compressed, with no indication that at least five years passed between

\footnotetext{
48 Ibid.

${ }^{49}$ Ibid., 170.

${ }^{50}$ Note also that the place of Thomas's father is rather different in the plea roll entry.
} 
offence and trial. It is entirely concerned with the steps in litigation before the king's justices. In particular it concentrates on procedural matters. Who is the primary defendant? Is the appellor a maimed man, or should he undertake proof by battle? Has the accusation been properly made? It then reports the form of proof, the outcome, and the punishment. The extra-legal material is therefore excluded. Now it could be that the back story, even if not in the form told by miracle account, did have influence, but this was not recorded in the plea roll. The report tells us that the jurors, (that is those reporting offences to the eyre, not jurors deciding the case, which went to trial by battle) 'well understand that that Thomas is guilty [culpabilis] of the wound and they know that the suit [i.e. preliminary accusation] was made as the coroners witness'. Yet this may be a purely factual assessment, rather than one taking into account the emotions involved.

Our second case concerns inheritance; again it is well known and is often called the Cockfield dispute. ${ }^{51}$ It is recorded in the Bury St Edmunds chronicle of Jocelin of Brakelond, in other Bury documents, in a final concord (that is a document recording a settlement in the king's court), and in a plea roll. It involves, on one side, the abbot and abbey of Bury and on the other the Cockfield family and others with connected interests. Relations between family and abbey do not seem to have been ones of long-standing conflict, although disputes over land at Cockfield had occurred as early as the Anglo-Saxon period. ${ }^{52}$

Let us start with Jocelin's account. ${ }^{53}$ Following the death of his father Robert, Adam of Cockfield came to the abbot and sought as his inheritance various lands and

${ }^{51}$ For earlier discussions, note Sir James Holt, Colonial England 1066-1215, London, 1997, 197-202; Hudson, Oxford History, 627-630; Joseph Biancalana. 'The Administrative Image of English Society and the Origins of the Common Law', (Unpublished paper, North American Conference on British Studies, Midwest Conference on British Studies, 27-28 October 1989), which also considers wider issues relevant to this article. Note how the bond of family to long-held land, a bond in part emotional, encouraged heritability.

${ }^{52}$ Holt, Colonial England, 200-201. For dispute in the Anglo-Saxon period, see Hudson, Oxford History, 133.

53 Jocelin of Brakelond, Chronicle, ed. and trans. H. E. Butler, London, 1949, 58-59. 
the half-hundred of Cosford. ${ }^{54} \mathrm{He}$ was accompanied by powerful supporters, including Earl Roger Bigod, presumably intended to instil fear if needed. The abbot made a gesture, a physical indication of his emotional commitment, to reinforce his response: he 'put two of his fingers against his two eyes and said "May I lose these eyes on that day and in that hour when I grant to anyone a hundred to be held by hereditary right, unless the king, who can take away my abbey and my life, should force me to do so"'. The situation was a request being made to the abbot, perhaps in his court, rather than formal litigation; the dramatic gesture may have been intended to counter the powerful array of people whom Adam had brought with him. However, Jocelin then describes the abbot as shifting to a different kind of discourse, setting forth his ratio, his argument, in the form 'if $\mathrm{x}$, then $\mathrm{y}$; if $\mathrm{y}$, then $\mathrm{z}$ ':

If any man should hold a hundred hereditarily, and should commit an offence against the king of such a kind that he ought to be disinherited, the sheriff of Suffolk and the king's bailiffs would immediately seize the hundred and exercise their power within our bounds; and if they had custody of that hundred, the liberty of the eight and a half hundreds [the abbey's specially privileged area] would be in peril.

After the abbot had expanded on these legal arguments, a large amount of money was offered to him, but Jocelin says it left him unmoved, and describes the money as a 'bribe [precium]'. The offer is being firmly placed outside the realm of law, although Adam might have said that he was offering a relief, the payment legally required for inheritance. Eventually a settlement was reached, but one that made no mention of the Cockfield itself; silence may have been used as a way to remove emotion from the dispute, and thereby to encourage restoration of peaceful relations.

Jocelin returns to the matter of Cockfield later in his Chronicle, when Adam died, leaving a three-month-old daughter as heiress. ${ }^{55}$ The issue arose of who should have the custody of the young girl. Again this was a matter of negotiation, of giftgiving, of influential friends. And again emotions heightened. The king, Richard I, grew angry with the abbot, and said 'with great indignation that he would avenge himself [se uindicaret] on the proud abbot who contradicted him, save that he desisted

\footnotetext{
${ }^{54}$ A half-hundred was an administrative unit, a division of the much more common hundred that was the administrative unit below the level of the county.

55 Jocelin, Chronicle, 97-99.
} 
out of reverence for St Edmund, whom he feared'. The abbot managed to assuage the anger and 'the king wrote in friendly fashion [amicabiliter] to the abbot and demanded that he should give him some of his dogs'. The abbot complied, and also sent other gifts, whereupon in the presence of great men the king praised the abbot's courage and loyalty 'and as a token of his friendship and love [signum familiaritatis et amoris]' gave him a valuable ring, once a gift to the king from the pope.

Finally Jocelin reaches litigation concerning the land. ${ }^{56}$ The wardship of Adam's daughter had been sold on to Thomas de Burgh, brother of the king's chamberlain. The abbey sought to keep in its hands three manors, Cockfield, Semer, and Groton, or at least Semer and Groton,

both because Robert of Cockfield on his deathbed had publicly said that he could claim nothing by hereditary right in those two manors, and because Adam his son had in full court reconsigned those two manors to us and made a charter concerning it, in which it was written that he held these two manors by grace of the convent for his lifetime only.

Jocelin's tone is precise and legal, and he goes on to display knowledge of legal terminology: Thomas sought 'a writ of recognition [breue de recognicione]', and made knights be summoned to Tewkesbury to swear before the king. However, his account of proceedings also reveals the influence of the extra-legal and emotional. At the hearing 'our charter was read out in public'. The knights themselves had justifications for ignoring the abbey's evidence, saying 'that they knew nothing about our charters nor about private agreements'. The abbey or at least Jocelin had a different explanation, one framed in terms that can be related to the emotional bias of those deciding the case: the reading of the charter 'had no impact, since the whole court was against us'.

Other relevant Bury documentation survives. As well as earlier charters, there are a list of certain lands that Adam of Cockfield held from the abbot, and a record by William of Diss concerning lands of Robert of Cockfield, including Robert's acknowledgment that he was not entitled to have any hereditary right in Groton and

\footnotetext{
${ }^{56}$ Ibid., 123-124.
} 
Semer. ${ }^{57}$ Neither the list nor William's record touches on matters of emotion. As for royal records, from 1191 we have a final concord; this reveals that Jocelin hid litigation concerning the half-hundred, which Adam of Cockfield brought against the abbot by a writ of mort d'ancestor, a royal order initiating an action concerning inheritance. ${ }^{58}$ The text is unusually detailed in its record of rent payments, but contains nothing concerning emotions. ${ }^{59}$ Finally we have a plea roll entry regarding the litigation over Cockfield, Semer, and Groton in $1201 .{ }^{60}$ The opening of the entry mirrors the language of the writ of mort d'ancestor, indicating how the writ standardized the issues that might be raised in the action: whether Adam was seised in his demesne as of fee farm of the lands on the day he died, and if his daughter was his closest heir. Elements significant in Jocelin's account are excluded. The case is presented as being between Adam's daughter, 'who is under age', and the abbey, with no mention of Thomas de Burgh. And, unsurprisingly, there is no mention of the bias of the court. Only one unusual phrase hints at the tensions between abbey and jurors. Normally the record would just specify what the jurors 'say'; here four extra Latin words have been inserted: 'but they well know that [set bene sciunt quod] ... the aforesaid Adam died seised thereof as of fee farm'. ${ }^{61}$

${ }^{57}$ The Kalendar of Abbot Samson of Bury St. Edmunds and Related Documents, ed. Ralph H. C. Davis, 3rd Series 84 Camden Society (1954), 71-72; Jocelin, Chronicle, 138-139.

${ }^{58}$ For a concise summary of mort d'ancestor, and the particular circumstances of its availability and use, see Hudson, Oxford History, 604-606. The lands concerned had to be heritable; in the Cockfield case this was phrased in terms of 'fee farm', i.e. lands held heritably for a fixed rent.

${ }^{59}$ Feet of Fines in the Public Record Office of the Reign of Henry II. and of the First Seven Years of the Reign of Richard I., 17 Pipe Roll Society (1894), no.11.

${ }^{60}$ Curia Regis Rolls, vol.1, 430.

${ }^{61}$ An alternative reading is that the extra words indicate that the justices had to persuade the jurors to be less cautious; if so, the jurors seem to have been less hostile to the abbot than Jocelin suggests. The issue of jurors' emotions affecting them is clear from Bracton's discussion (ed. Thorne, vol.2, 71) of exceptions to jurors, i.e. the raising of issues that would lead to their exclusion; grounds included 'enmity, great not light, and present, not that which once existed but no longer exists at the time the 
The preceding analysis reveals the differences between reports of cases in various types of source. The differences are partly a matter of genre, and of assessment of what is significant. But there is a further factor, the portion of the dispute which the text is describing. Thus the plea roll is focused on formal litigation in court; it is noteworthy that in Jocelin too and even in the Worcester miracle story, the degree to which the emotions of participants forms part of the account of the formal litigation is limited. Emotion is more prominent on other occasions when legal matters were raised, for example the initial request for the inheritance in the Cockfield case. The analysis therefore not only suggests that legal sources may deliberately have excluded matters of emotion, but also again indicates that when assessing the relationship between law and emotion, one must distinguish different fields: thinking about law in general; legal matters outside court; law in court, i.e. litigation, and within that field, law in court as it was supposed to be and law in court as it might be in practice.

Examination of the plea rolls therefore confirms the impression gained from Glanvill that legal sources largely attempted to exclude matters of emotion. Such exclusion was not completely new with the development of the common law in the later twelfth century. For example, twelfth-century English charters tend to the concise and formulaic, excluding the type of narrative material sometimes [sometimes?] present in land conveyances in other places or periods; there is a sense of an appropriate legal register of language. ${ }^{62}$ Or take final concords, the records of agreed settlements. These might easily have routinely included at least the language of emotion. Glanvill's discussion of concords made in the king's court starts: 'it often happens that pleas begun in the lord king's court are ended by amicable composition and final concord'. ${ }^{63}$ Of course 'amicable' need not indicate real emotion, but the use

juror is produced. Also because of present friendship, just as because of hatred'. Note Rotuli Curice Regis, vol.1, 321 for a party stating that not all those who viewed whether he really was ill were knights and that all were his mortal enemies. Cf. Smail, Consumption, 95-117, on exceptions to witnesses in Marseille.

${ }^{62}$ See in general Hudson, Land, Law, and Lordship.

${ }^{63}$ Glanvill, Bk viii ch. 1, ed. Hall, 94. See more broadly on love and settlements, e.g. Michael T. Clanchy, 'Law and Love in the Middle Ages', in J. Bossy, ed., Disputes and Settlements: Law and Human Relations in the West, Cambridge, 1983, 47-67. 
of the term remains noteworthy, in contrast to the general absence of emotion words from final concords themselves. ${ }^{64}$ This is true too of final concords even before copies were routinely kept by the royal government from 1195 onwards. ${ }^{65}$ Yet the exclusion of matters and language of emotion in the records of litigation from the early common law period remains significant, and as I have suggested indicates deliberate decisions as to what is required in a legal record and, less directly, what is important in litigation and law more widely.

Was the same true of the earliest surviving official records from ecclesiastical courts in England? Given the interest of ecclesiastical writers such as Thomas of Chobham in issues of motivation and emotion, one might have expected the ecclesiastical court records to be different in content and perhaps tone from the royal ones. ${ }^{66}$ The records survive from much the same time as the earliest plea rolls, and are associated with a figure who may have had a very significant influence on royal record-keeping, Hubert Walter, leading royal official and archbishop of Canterbury. ${ }^{67}$ Because they relate to trials held according to canonical procedure, these records are of a very different nature from the royal plea rolls. In particular they include depositions of witness statements. These perhaps might be expected to be more concerned with matters of emotion, but in fact the depositions give little space to such matters, presumably reflecting what the ecclesiastical judges or their officials considered important. If emotions are mentioned, or emotion words are used,

${ }^{64}$ Cf. Curia Regis Rolls, vol.1, 425, for a party mentioning an agreement by royal licence which involved not just a quitclaim and homage but also a kiss of peace and the pardoning of all ill-will.

${ }^{65}$ For use of emotion vocabulary, note the mention of 'love of God' being part of the inspiration for settlement in English Lawsuits from William I to Richard I, ed. and trans. R. C. van Caenegem, 106, 107 Selden Society (1990, 1991), no.572.

${ }^{66}$ Note the very interesting discussion of Thomas's writings in Hyams, Rancor, 48-

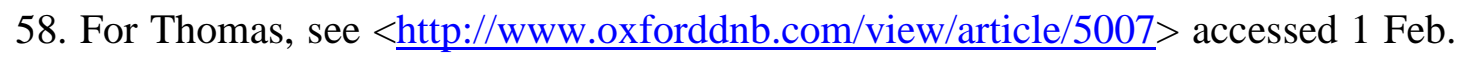
2017.

${ }^{67}$ Select Cases from the Ecclesiastical Courts of the Province of Canterbury, c. 12001301, ed. and trans. Norma Adams and Charles Donahue, 95 Selden Society (1981). For Hubert, see <http://www.oxforddnb.com/view/article/28633> accessed 1 Feb. 2017. 
occurrences tend to be in information regarding the background to the court case rather than points of particular legal consequence. A certain William de Plaiz 'came to the bishop [of Bath] weeping [flens] and saying "My lord R., I shall not be a canon of Wells any more, and I will be degraded henceforth among my fellows”, and the bishop, moved by his tears [motus ad lacrimas eius]..., conceded to him that he would be a canon'. ${ }^{68}$ Fear might be mentioned, but with no great emotional content, and not necessarily as a legal justification for an action. Thus a party in a dispute explains that a clerk was staying in a church to guard it 'because they feared [timebant] that a certain knight who claimed for himself the right of patronage in it might enter into it'. ${ }^{69}$ There are some issues where emotion language within testimony could have legal import, for example as to whether a couple were married: it might be stated that the man 'honoured' the woman 'and held her dear [caram] as [tanquam] his wife'. ${ }^{70}$ There are also comments on how witnesses gave testimony, comments that may suggest an effect on the weight that would be given to their words: one 'seemed ... to speak lukewarmly, and not constantly, and to offer a premeditated speech', another - whose testimony varied - spoke 'timidly and with trepidation'. Here an assessment of the emotional state of the witness, based on somatic as well as verbal signs, could have some legal consequence. ${ }^{71}$

Besides depositions we have also a notification of complaints of the prior and convent of Rochester against their bishop. Here emotion language is used to give force to the complaints:

Sighing from the lake of miseries and oppressions, looking to the equity of your pondering, in the bowels of mercy of our God we ask relief from this grave yoke, that having the fear of God here before your eyes, here the rights

\footnotetext{
${ }^{68}$ Select Cases, A.4 (at 14). Note also e.g. hatred mentioned in A.6 (at 19) as part of the explanation as to why a man did not want his kinsfolk at his side at his espousal. ${ }^{69}$ Ibid., A.4 (at 12; see also 13).

${ }^{70}$ Ibid., A.6 (at 22).

${ }^{71}$ Ibid., A.6 (at 21, 22). A further deposition mentions the terrorising of witnesses, a legal issue in itself; ibid., A.12 (at 37). On matters affecting witnesses and jurors in secular law, note Hyams, Rancor, 40-43.
} 
of our liberties carefully exploring, you may please the right Judge whose eyes see all rights by judging the right of every right. ${ }^{72}$

In addition, fear again becomes a legal issue, fear which also perhaps has a greater emotional content than in some other instances. The prior and convent mention that 'out of fear ... of his [i.e. the bishop's] power, since we could not prevent and feared greater, we suspended prosecution of our appeals'. And they specify that 'in all of these matters we can prove probable fear which can fall on a most constant man'. This alludes to the 'constant man' test for invalidating a legal act on grounds of fear, a test that appears in canon law. ${ }^{73}$

So, as in the common law records, we find in the ecclesiastical court records that mentions of emotion and use of an emotional vocabulary depended on situation. They are more present, as one would expect, in petitioning, and similarly appear in requests, petitions, and complaints to the king. ${ }^{74}$ In witness depositions to ecclesiastical courts appear the type of back-story largely absent from common law records, and these sometimes include descriptions of emotion or emotion language, with the narrative being constructed in a way that may have been intended to affect the emotions of those hearing the case. ${ }^{75}$ Emotions are largely absent from issues of litigation. As we have also seen in examining the Thomas of Elderfield and Cockfield cases, the limits of mention of emotion in courtroom litigation need not just be a

${ }^{72}$ Select Cases, A.15 (at 41); note also the whipping up of emotional effect at 45-46 ('bestowal on gluttons' and so on), and at 46 (suffering with bitterness of spirit, as well as a further reference to fear). Note further the presentation (at 42) of a good bishop as one who treated the monks of his church with 'paternal affection' and nourished them 'with a maternal breast'. Some such lengthy complaints may reflect rhetorical training and rhetorical learning on emotions; see e.g. Copeland, 'Affectio', esp. 11-20.

${ }^{73}$ Select Cases, A.15 (at 45). For the canonical reference, see the Liber Extra, X. 4.1.16).

${ }^{74}$ Note e.g. English Lawsuits, no.351; also e.g. Curia Regis Rolls, vol.3, 14, to the king's justices.

${ }^{75}$ See below, 000, on the possibility that pleaders might have sought to introduce such material into common law courts, but without this featuring in the records. Note also Kamali, 'The Devil’s Daughter'. 
product of the legal record, of its genre and purpose; it could reflect what was considered proper to legal process at a particular stage.

The unemotional tone of the records of litigation in the king's court, therefore, is partly a matter of the nature of the record, but also reflects other factors, including the fact that a great mass of court business was routine. Amidst the few dramatic cases were a plethora of excuses for non-attendance, appointments of attorneys, and so on. The increasing presence of attorneys rather than the litigants themselves may on occasion have changed or reduced the emotions of the courtroom, especially if the attorneys were not closely related to those whom they were representing. ${ }^{76}$ Indeed, the atmosphere of royal courts for much of their extended terms may have been very different from the single day and periodic sittings of, say, county courts, with their very diverse business. Scribal injections of humour into the plea rolls suggest that even the clerks of the courts found the experience dull. ${ }^{77}$ And the image of legal proceedings emerging from records, with its strongly administrative tone, could become self-reinforcing. Justices' clerks might become justices, justices controlled proceedings of the courts, and litigants would learn what was effective in winning their cases. Litigation in court thus became more distanced from other aspects of life.

\section{FURTHER POSSIBILTIES}

Many further aspects of the relationship between law and emotions could be examined. Some of these already have been examined by others with conscious reference to the history of emotions, for example Paul Hyams' exploration of possible theological reasons for ecclesiastical courts not having adversarial process. ${ }^{78}$ Other existing studies, for example of juries modifying outcomes of accusations, can be taken further when informed by specific examination of emotions. ${ }^{79}$ One might also look at how common emotional assumptions affected procedure, even though the

\footnotetext{
${ }^{76}$ Paul A. Brand, The Origins of the English Legal Profession, Oxford, 1992.

${ }^{77}$ Flower, Introduction to the Curia Regis Rolls, 7-8.

${ }^{78}$ Hyams, Rancor, 55.

${ }^{79}$ Green, Verdict According to Conscience; Kamali, 'The Devil’s Daughter', and also Elizabeth Papp Kamali, A Felonious State of Mind: Mens Rea in Thirteenth- and Fourteenth-Century England (PhD dissertation, University of Michigan, 2015).
} 
emotions might be left implicit. The attachment of son to father allowed him to act as witness and participant in trial by battle in a land case when his father died; Glanvill phrases this in terms of 'the faith by which son is bound to father' ${ }^{80}$ The greatest contrast would be with the professional champion, who was clearly strongly disliked, Thomas of Chobham writing of such men's 'fraternal hatred' 81

Another potentially fruitful area of study is the routinized use of emotionrelated words in law. For example, there is the notion of contempt, be it of an order or of a court. ${ }^{82}$ Glanvill frequently mentions contempt of court, leading to the offender being punished or at least being in the king's mercy, that is owing a monetary penalty. ${ }^{83}$ In particular one might examine the wording of the new, routine writs that were at the centre of the actions of the early common law, writs such as that of mort d'ancestor which we encountered in the Cockfield case. Their tone is very different from the apparently unroutinized earlier statements of emotion, as in a writ of Henry II, possibly from 1155:

I am astonished and greatly displeased that you have not done what I ordered you in my other writs concerning the manor of Heatherslaw, which the monks of Durham claim. Now, moreover, I firmly order you on my forfeiture to execute my order without delay so that I hear no further complaint [clamorem] on this matter for want of full justice. ${ }^{84}$

It is of course dangerous simply to read such statements as unmediated descriptions of the king's emotions. Royal fury could, to varying extents, be formalized, as Jolliffe

${ }^{80}$ Glanvill, Bk ii ch. 3, ed. Hall, 23. Note the mentions of shame in Glanvill: see esp. Bk ii ch. 7, ed. Hall, 28, with reference to 'the reproach of the perpetual disgrace which follows that distressed and shameful word which sounds so dishonourably from the mouth of the vanquished' in trial by battle; Bk xiv ch. 6, ed. Hall, 176, concerning marriage after rape.

81 Hyams, Rancor, 53; Thomas de Chobham, Summa Confessorum, ed. F. Broomfield, Louvain, 1968, 293.

${ }^{82}$ For contempt of a royal order, see e.g. English Lawsuits, no.446.

${ }^{83}$ See Glanvill, Bk i chs. 31, 32, 33, iii ch. 6, xiii ch. 10, ed. Hall, 20-21, 42, 153.

${ }^{84}$ English Lawsuits, no.361C. 
showed in his study of Angevin 'anger and ill-will [ira et malevolentia]' ${ }^{85}$ Nor do expressions of particular royal anger disappear when the routine common law writs emerge. However, the exceptional statements of anger can be contrasted with the standardized ending of certain routine common law writs, in which any emotional element of the threat has become veiled: for example, 'and if you do not do it, the sheriff will, that s/he need not complain further on this matter for default of right' ${ }^{86}$

Moreover, in the routine writs of the common law, some state that the person bringing the case was 'complaining [queri or conqueri]', as opposed, for example to 'seeking' or 'claiming' ${ }^{87}$ It may be that the word 'complain' retained traces of its emotional charge, at least in comparison with other words such as 'to seek': these were cases where the litigant was saying that the opponent had done something to them, rather than just being in possession of something that was theirs. Some writs open with the phrase 'It has been complained to me': when the litigant complained that his opponent was seeking to reduce him to villeinage; ${ }^{88}$ or that his mother had more of his inheritance as dower than she should; ${ }^{89}$ or that someone had unjustly and

85 J. E. A. Jolliffe, Angevin Kingship, London, 1955. Formalization of course need not have made royal anger any less frightening for its victims. For a broader European context, see e.g. Gerd Althoff, 'Ira Regis: Prologomena to a History of Royal Anger', in Rosenwein, Anger's Past, 59-74. Note also the discussions in White, 'Feelings in the Feud', and Daniel Lord Smail, 'Hatred as a Social Institution in Late-Medieval Society', 76 Speculum (2001), 90-126.

${ }^{86}$ Glanvill, Bk vi ch. 5, xii chs. 5, 10, ed. Hall, 61, 138, 141. Cf. Glanvill, Bk xii ch. 4, ed. Hall, 138, using the word 'clamor'.

${ }^{87}$ I have found no clear distinction of meaning between 'queri' and 'conqueri'. For 'petere', 'to claim' or 'to seek', see e.g. Glanvill, Bk xiii chs. 2-3, ed. Hall, 149-150, on mort d'ancestor. Note that the distinction is not so clearly maintained in the plea rolls, particularly the earliest ones; see e.g. Rotuli Curice Regis, vol.1, 64, 315, 369, vol.2, 66, 117, 213, Curia Regis Rolls, vol.1, 185, vol.3, 134, 135, for parties bringing novel disseisin being referred to as petentes; ibid., vol.2, 121, for parties bringing mort d'ancestor being referred to as querentes.

${ }^{88}$ Glanvill, Bk v ch. 2, ed. Hall, 54.

${ }^{89}$ Glanvill, Bk vi ch. 18, ed. Hall, 68-69. This instance may seem rather different to the others, more like the claim of unjustified possession rather than the doing of a 
without judgment disseised him of his free tenement. ${ }^{90}$ The first writ in Glanvill, sometimes referred to as Precipe quod reddat, speaks in terms not of a claim to right to land, but of a complaint that another is 'withholding' land from the person bringing the writ; again, the focus is on the wrong done to the litigant. ${ }^{91}$ The verb 'to complain' is also used, for example, with reference to impleading concerning the advowson of a church in an ecclesiastical court, when it should happen in the king's court; ${ }^{92}$ or to an opponent detaining a debt, ${ }^{93}$ or detaining distrained moveables; ${ }^{94}$ or to the denial of justice. ${ }^{95}$ Glanvill himself uses the participle 'conquerens', i.e. 'complaining', with reference to a woman who is complaining that her proper dower is being withheld; ${ }^{96}$ a party complaining that a final concord has not been kept; ${ }^{97}$ and a debtor complaining that his creditor is still maliciously retaining a gage despite the debt having been paid. ${ }^{98}$

Use of the word 'complain' therefore characterizes pleas where the party is focusing on a wrong done by the opponent. Such may be seen as forming one fundamental category of pleas. The other fundamental category is where the party seeks something that is in the opponent's possession, claiming that it belongs to him

wrong; however, the choice of the word 'complain' in the writ suggests contemporary perceptions of the form of wrong.

${ }^{90}$ Glanvill, Bk xiii chs. 33-37, ed. Hall, 167-168.

${ }^{91}$ Glanvill, Bk i chs. 5-6, ed. Hall, 5.

${ }^{92}$ Glanvill, Bk iv ch. 14, xii chs. 21, 22, ed. Hall, 53, 146.

${ }^{93}$ Glanvill, Bk x chs. 1-2, ed. Hall, 116; see also Bk x chs. 4, 6, 7, ed. Hall, 118, 121122.

${ }^{94}$ Glanvill, Bk xii chs. 12, 18, ed. Hall, 142, 144; see also Bk xii ch. 13, xiii ch. 38, ed. Hall, 142, 170. Note also Bk ix ch. 4, ed. Hall, 109, on the persistent refusal by a lord to accept homage and relief; Bk xii ch. 9, ed. Hall, 141, on unjust demands for customs and services.

${ }^{95}$ Glanvill, Bk xii ch. 7, ed. Hall, 139; and routinely in the phrase 'that s/he need not complain further on this matter for default of right', above, 000.

${ }^{96}$ Glanvill, Bk vi ch. 11, ed. Hall, 64.

${ }^{97}$ Glanvill, Bk viii ch. 3, ed. Hall, 96-97.

${ }^{98}$ Glanvill, Bk x ch. 8, ed. Hall, 124. Note also e.g. Glanvill, Bk ix ch. 13, ed. Hall, 115. 
or her. ${ }^{99}$ Such a claim may then be supplemented by complaint of witholding, and some writs combine the two elements: 'Command N. that justly and without delay he release the advowson of the church ... to R., who claims that it belongs to him and complains that $N$. unjustly withholds it from him' ${ }^{100}$ Claim and complaint are thus distinguished clearly. In such ways, considering the routinized use of once emotionally-charged words can have obvious significance for the historian of law; less directly, it should also be of major interest the historian of emotions.

\section{CONCLUSIONS}

This article has been concerned with the relationship of emotions and law in the Angevin period. It began by suggesting that those interested in the relationship of emotions and law can profitably look at a multiplicity of functions of law and of situations in which law comes into play. Next, in considering the alienability of land, we saw how law could be used to further people's emotion-inspired aims, through the legal securing of grants. Yet legal developments during the period also encouraged in various ways some aspects of law to become more discrete from emotions, at least in certain circumstances. Such a distancing may in part have been an unplanned extension of the use of law to counter the effects of what were seen as excessive or improper or transient emotions. The notion that law could have this purpose may then have encouraged the view manifest in Glanvill that law was closely associated with reason, ratio, at least implicitly contrasted with emotion, in Latin sometimes affectio. Next the article argued that whilst new official records give a particular perspective on the inter-actions of law and emotion, this perspective not only can be clarified by

\footnotetext{
99 See Hudson, Oxford History, 70, for further elaboration of this argument.

${ }^{100}$ Glanvill, Bk iv ch. 2, ed. Hall, 45; the basic form of Precipe, cited above, 000, does not refer to a claim, just to the wrongful withholding. Note also the form of the writ of right in Glanvill, Bk xii ch. 5, ed. Hall, 138. Cf. Glanvill, Bk vi ch. 15, ed. Hall, 66, concerning dower. Note the deforciant clause in later writs of right, which are used in conjunction with reference to claims to hold land from the addressee. In the earliest Register the deforciant may but need not be the addressee, in subsequent Registers the deforciant appears distinct from the addressee; Early Registers, Hib. 1; cf. CA. 1 , CC. 1 , R. 1.
} 
examining other types of source but may also have reflected and reinforced attitudes with important effects on legal development. It ended by exploring how the imprint on legal discourse of routinized, but possibly once emotionally-charged, vocabulary can be revealing to legal historians.

It is important not to exaggerate the degree of change, of distancing of law from emotion, in this period. Perception of the proper relationship of law and emotion might depend on the type of legal situation, for example petitioning as opposed to litigation, and also on the view-point of different parties. We have seen how emotions might affect legal matters outside court. We also hear, for example, of innocent parties fleeing through fear of accusation, their flight having legal consequences for themselves. ${ }^{101}$ Emotions underlay disputes and might motivate the bringing of actions. And emotions could unjustly affect proceedings in court - at least in the eyes of the losing party. It may well be that as specialist attorneys appeared, one of their skills was in manipulation of emotion, one of the traditional skills of forensic rhetoricians; was such manipulation a talent of John Bucuinte, that is John 'Oily mouth'? ${ }^{102}$ As for judging, Glanvill emphasizes impartiality as a virtue, with impartiality arising from being guided by the laws of the realm and by customs which have their origins in reason. ${ }^{103}$ However, narrative depictions of Angevin kings acting as judges do not differ significantly from those of their predecessors. Favour and emotion may have entered particularly into the king's judicial activities in relation to those who held their lands directly from him. Cases involving such 'tenants-in-chief' were not covered by routine procedures in the way that other tenants' litigation had come to be, and their treatment might anyway be more politically charged. ${ }^{104}$

Yet the changes remain significant. Some of the process of distancing may have been intended, some an indirect result or by-product of other developments. ${ }^{105} \mathrm{It}$ may be that the justices who heard pleas in place of the king often although not invariably encouraged routinization, removing emotional and other factors from court.

\footnotetext{
${ }^{101}$ Hurnard, Pardon, 131.

102 Hudson, Oxford History, 587-588.

103 Glanvill, Prol, ed. Hall, 1-2.

${ }^{104}$ See esp. Sir James Holt, Magna Carta, 3rd edn, Cambridge, 2015, ch. 5.

105 See e.g. above, 000, on control of excessive emotion, 000, on court business and record keeping; cf. above, 000-00, on writs and exceptions de odio et atia.
} 
They were often outsiders, with little or no interest in the parties. ${ }^{106}$ Emotion might be the motive for bringing an action, but that action needed to be valid in legal terms, and when necessary emotion had to be set aside in its conduct. ${ }^{107}$ The lack of an earlier equivalent prevents comparison, but the generally emotionless, logical tone of Glanvill as a procedural manual does seem significant. ${ }^{108}$ Such a distancing of law from emotion fits with instances of distancing of secular law from social norms as well as from religion - a mortgage was, according to Glanvill, not simply 'unjust and dishonourable' but also a form of usury and by implication sinful, yet it was not forbidden by the king's court. ${ }^{109}$ Law could, by its internal logic expressed in its own particular discourse, reach socially and emotionally unexpected conclusions. This is clearest in Glanvill but could also be manifest in litigation. Law's tendency to fit a wide diversity of situations into a limited number of set forms became considerably stronger in the Angevin period. This process had the effect of excluding much from litigation, and treated other matters - including, as we have seen, some relating to emotions - in a particular, restricted and formalized way.

The predominant view-point in the article has been that of royal justices; others must at times have thought not that emotions were wrongly intruding into matters of law but that law was wrongly constraining matters of emotion. Furthermore, if law was being further separated from emotion, the very distancing of law from social expectation inevitably produced emotional responses. In 1192 the monks of Bury complained to their abbot that they were not receiving additional revenue from the borough, despite its growing wealth. ${ }^{110}$ The burgesses' resistance

106 Note also Jocelin, Chronicle, 34: having just mentioned Abbot Samson's appointment as a royal itinerant justice, Jocelin states that 'his men complained to him in the court of St Edmund, because he would not rush to judgment, nor "believe every spirit”, but proceeded in accordance with judicial process, knowing that the merits of cases are revealed by the statements of the parties'.

${ }^{107}$ See e.g. English Lawsuits, no.641. For a case brought out of malice by Ranulf de Glanville, see ibid., no.553.

${ }^{108}$ Hudson, 'Leges to Glanvill', provides arguments as to why the change should be seen as more than just the appearance of a new type of source.

${ }^{109}$ See Glanvill, Bk x ch. 8, ed. Hall, 124; Hudson, 'Leges to Glanvill'.

110 Jocelin, Chronicle, 78-79. 
provoked annoyance, perhaps anger amongst the monks, who asked that the abbot disseise the burgesses of their holdings. The abbot expressed his sympathy, but said he had to proceed by judicial process and could not disseise free men of their lands without judgment of a court; otherwise he would fall into the king's mercy by the assize of the realm. The monks decided they had to put up with the existing situation, but eventually the abbot agreed to confirm the town's liberties. Again the monks had to accept this, but the matter was clearly one of some emotion and also of emotional calculation; the monks did not wish to provoke the abbot to anger, but still they murmured and grumbled. The pattern of interplay between law and emotion might have changed, but it had most certainly not disappeared.

\section{CODA}

This paper has been concerned with the relationship of law and emotion, and of the history of law and the history of emotions. I have argued that one characteristic of the development of the early common law was that some aspects of law, of legal thought, legal process, legal record, grew more discrete from emotion. At the same time, the argument rests to an extent on a certain conception of what is law and of what is legal history. Such conceptions are of course contested, and the relationship between law and emotion, and between the history of law and the history of emotions, will be greatly affected by one's conception of law and of legal history. A legal positivist will take a different view from a proponent of critical legal studies, a legal realist a different view from a proponent of law and economics. ${ }^{111}$ Historians interested in legislation and royal administration of justice will differ from those interested in processes of disputing, those interested in the social functioning of law and participants' decision-making will differ from those interested in elementary legal

${ }^{111}$ Likewise differences may exist within such broad jurisprudential fields; for one approach in which issues of emotions clearly are of importance, note e.g. Christine Jolls, Cass R. Sunstein, and Richard Thaler, 'A Behavioral Approach to Law and Economics', 50 Stanford Law Review (1998), 1471-1550. Of course thinking about emotions is diverse, just as is thinking about law, and has an effect on thinking about the relationship between the two; see e.g. Abrams and Keren, 'Who's Afraid of Law and the Emotions?'; Bandes, Passions, 11-12. 
ideas and their development. Different conceptions of law and of legal history draw different boundaries between the legal and the extra-legal. These differing boundaries have considerable implications for the relationship between law and emotion. But these issues need not be seen as frustrating analysis of law and emotion; rather by posing questions, stimulating debate, they should encourage the fertile development of this important field.

\section{Note on Contributor}

John Hudson is Professor of Legal History and Director of the Institute of Legal and Constitutional Research at the University of St Andrews. 